\title{
Response of the mixed prairie to protection from grazing
}

\author{
WALTER D. WILLMS, JOHAN F. DORMAAR, BARRY W. ADAMS, AND HARRIET E. DOUWES
}

Walter D. Willms, Johan F. Dormaar, and Harriet E. Douwes are Range Ecologist, Soil Scientist (emeritus), and Range Technician, respectively, Agriculture and AgriFood Canada, PO Box 3000, Lethbridge, Alberta, Canada TIJ 4B1; Barry W. Adams is Range Specialist, Alberta Agriculture, Food and Rural

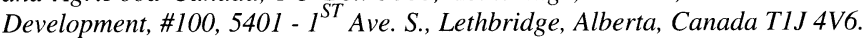

\section{Abstract}

The Mixed Prairie plant communities developed with the influences of fire and grazing. Available evidence suggests that removal of these disturbances could cause succession toward a more mesic type with the accumulation of litter or loss in productivity as nutrient turnover is delayed. Exclosures constructed in 1927 in a semiarid Mixed Prairie community provided an opportunity to examine the effects that protection had on vegetation and soils. Fifteen exclosures were selected for detailed examination; of these, 11 were located on Chernozemic soil and 4 on Solonetzic soil. We measured plant and soil variables both inside and outside the exclosures in a test of the hypothesis that protection from grazing will lead to a loss of production potential of the semi-arid. Mixed Prairie communities in the Northern Great Plains of southeastern Alberta. We found little evidence that 70 years of protection from large animal disturbance reduced the production potential of the plant communities. Conversely, most evidence suggested a neutral effect or an improvement as reflected in an increased cover of Pascopyrum smithii Rydb. (Löve) $(P=$ $0.049)$ and increased annual net primary production $(P=0.047)$. The effect of protection appeared largely driven by the accumulation of litter mass that primarily benefits soil and plant indices of quality on the Chernozemic soil type. Although protection tended to reduce species diversity $(P=0.097)$ among native plants on the Chernozemic soil type, evenness and richness were not affected $(P>0.10)$. The potential effect that reduced diversity might have on reducing production stability appears more than compensated for by increased litter mass.

Key Words: Soil nitrogen, soil depth, botanical composition, plant biomass, plant nitrogen

The Northern Great Plains developed under a system of periodic use by bison and occasional fire. Fire prevention has effectively eliminated the greatest disturbance that prevented litter buildup and arrested succession to more mesic conditions. Presently, the primary means of disturbance is from grazing by cattle. Without disturbance, the mesic grasslands are encroached upon by shrubs and eventually trees, while on drier sites the communities become more representative of those found in less arid conditions (Lauenroth et al. 1994) as soil moisture retention improves

\footnotetext{
The authors wish to thank Mr Allan Ross, who was manager of the Onefour substation at the time of the study, for help in facilitating the research.

Manuscript accepted 17 Aug. 01
}

\section{Resumen}

Las comunidades de plantas de la Pradera Mixta se han desarrollado bajo la influencia del fuego y del pastoreo. Las evidencias disponibles sugieren que la remoción de estos disturbios podrían causar una sucesión hacia tipos de comunidades con más humedad disponible, con la acumulación de residuos o pérdidas en productividad debido al retraso en el reciclado de nutrientes. Parcelas aisladas en 1927 en una comunidad semiárida de Pradera Mixta brindaron la oportunidad de examinar los efectos de la protección sobre la vegetación y los suelos. Quince parcelas aisladas fueron seleccionadas para un exámen más minucioso; de éstas, once fueron localizadas en suelos Chernozémicos y cuatro en suelos Solonetzicos. Se midieron variables relacionadas con plantas y suelo, dentro y fuera de las parcelas aisladas, en una investigación experimental en que la hipótesis era que la protección contra el pastoreo llevaría a una pérdida potencial de producción en las comunidades de la zona semiárida de la Pradera Mixta en las Grandes Llanuras del Norte en el sudeste de Alberta. Se encontró poca evidencia que en setenta años de protección contra disturbios causados por grandes animales se redujera el potencial de producción de las plantas de la comunidad. Por el contrario, los resultados sugirieron que el efecto sería neutral o incluso se produciría una mejora como se reflejó en el incremento en la cobertura de Pascopyrum smithii Rydb. (Love) $(P=0,049)$ y un incremento en la producción primaria neta anual $(P=0,047)$. El efecto de la protección pareció en mayor medida influenciado por la acumulación de masa de cama de paja que beneficia primeramente los índices de calidad de suelo y plantas en el suelo Chernozémico. Si bien la protección tendió a reducir la diversidad de las especies $(P=0,097)$ entre las plantas nativas en el tipo de suelo Chernozémico, la uniformidad y la riqueza no fueron afectadas $(P>0,10)$. El efecto potencial que la reducción en la diversidad tendría sobre la reducción de la estabilidad productiva parece estar más que compensado por el incremento en la acumulación de residuos.

with litter accumulation. Grazing can enhance species diversity on grasslands but that response appears linked to the moisture regime of the site (Milchunas and Lauenroth 1993).

Since the Mixed Prairie developed under the influence of grazing by large animals, the proposition seems reasonable that grazing impact is required to maintain it (Savory 1983). Unfortunately, we have no way of ascertaining the pre-European conditions but we can assess the effects that protection from grazing has on the plant community. Protection from grazing has been recognized as a strategy to improve range condition although 
under specific conditions, i.e. grasslands with a long evolutionary history, low annual net primary production, and few years of grazing treatment (Milchunas and Lauenroth 1993). The construction of exclosures in 1927, within the most arid portion of the Northern Great Plains in Canada, provided an opportunity to study the effects of long-term protection from large animal impact on the ecology of the grassland in a study to test the hypothesis that protection from grazing is detrimental to the health of the Mixed Prairie community. In this study, vegetation and soil characteristics were compared between ungrazed paddocks and paddocks stocked at light to moderate stocking rates (Wroe et al. 1988). The objective was to compare the effects that protection from grazing had on soil and vegetation properties on 2 common soil types.

\section{Materials and Methods}

The study was conducted at the Agriculture and AgriFood Canada substation at Onefour in southeastern Alberta $\left(49^{\circ} 07^{\prime}, 110^{\circ} 28^{\prime}\right)$ at $935 \mathrm{~m}$ elevation. Long-term average annual precipitation and average daily temperature was 332 $\mathrm{mm}$ and $4.6^{\circ} \mathrm{C}$, respectively, while the long-term average precipitation and daily average temperatures for the period from April to September was $226 \mathrm{~mm}$ and $13.8^{\circ}$ C, respectively. In 1996 and 1997, precipitation from April to September was 245 and $219 \mathrm{~mm}$, respectively, while average daily temperatures were 13.9 and $14.4^{\circ} \mathrm{C}$, respectively. While the predominant plant community is representative of the StipaBouteloua faciation on Orthic Brown Chernozemic (Aridic Haplustoll) soil, another important type is the Agropyron smithii [ie Pascopyrum smithii Rydb. (Löve)] consocies on Brown Solodized Solonetzic (Aridic Natrustoll) soil (Coupland 1950).

In 1927, when the Onefour substation was established, at least $26,11 \times 11 \mathrm{~m}$ exclosures were constructed on various grassland types throughout an area of $5 \mathrm{x}$ $10 \mathrm{~km}$. Fencing of the current paddocks began in 1927 and all were in place by 1938 when they appear on the earliest available map of the area. A preliminary examination of the exclosures in 1995 revealed that 15 were suitable for inclusion in the study. Exclosures were eliminated from the study if the plant communi- ty in, or around them, had been compromised by invasion with crested wheatgrass (Agropyron cristatum (L.) Gaertn.) or were located on a knob or in a depression that created a habitat type not represented in the immediate vicinity.

A history of grazing management was not available until 1992 when records began to be kept of stocking rates in the various paddocks. However, early studies, begun in 1931 at the substation, established an acceptable stocking rate of about $0.5 \mathrm{AUM} \mathrm{ha}^{-1}$ (Smoliak and Peters 1952) but that could vary from 0.35 to 0.62 AUM ha ${ }^{-1}$ (Clarke et al. 1942), and 0.43 AUM ha ${ }^{-1}$ was considered to be "very moderate" (Clarke et al. 1947). The targeted stocking rate was $0.43 \mathrm{AUM} \mathrm{ha}^{-1}$ from 1949 to 1964 (Smoliak, Personal Communication) and was believed to be the goal since then. Later published stocking rates recommended 0.37 to 0.74 AUM $\mathrm{ha}^{-1}$ (Wroe et al. 1988), depending on the condition of the grassland. From 1992 to 1997 the average stocking rates ranged from 0.25 to $0.67 \mathrm{AUM} \mathrm{ha}^{-1}$ and the onset of grazing was mostly in late summer (Table 1) and completed by December. The original recommended stocking rates were designed to utilize an average of $55 \%$ of standing crop (Clarke et al. 1942) while long-term estimates of production were $388 \mathrm{~kg} \mathrm{ha}^{-1}$ (Smoliak 1986) measured from 1930 to 1983 .

Table 1. Location and soils of 15 exclosures and their grazing management over 6 years from 1992 to 1997.

\begin{tabular}{|c|c|c|c|c|c|}
\hline \multirow{2}{*}{ Field } & \multirow{2}{*}{ Field size } & \multirow{2}{*}{ Soil type } & \multicolumn{2}{|c|}{ Grazing period (month, yr.) ${ }^{1}$} & \multirow[t]{2}{*}{ Stocking rate ${ }^{2}$} \\
\hline & & & Starting & Ending & \\
\hline & (ha) & & & & $\left(\mathrm{AUM} \mathrm{ha}^{-1}\right)$ \\
\hline \multicolumn{6}{|c|}{ Chernozemic } \\
\hline A & 1765 & Orthic Brown & Aug. (1); Sept. (5) & Oct. (1); Nov. (5) & 0.25 \\
\hline A & 1765 & Orthic Regosol & Aug. (1); Sept. (5) & Oct. (1); Nov. (5) & 0.25 \\
\hline A & 1765 & Orthic Brown & Aug. (1); Sept. (5) & Oct. (1); Nov. (5) & 0.25 \\
\hline A & 1765 & Brown Solod & Aug. (1); Sept. (5) & Oct. (1); Nov. (5) & 0.25 \\
\hline A & 1765 & Orthic Brown & Aug. (1); Sept. (5) & Oct. (1); Nov. (5) & 0.25 \\
\hline $\mathrm{B}$ & 1330 & Orthic Brown & May (2); Aug. (4) & Oct. (2); Nov. (4) & 0.48 \\
\hline B & 1330 & Orthic Brown & May (2); Aug. (4) & Oct. (2); Nov. (4) & 0.48 \\
\hline $\mathrm{C}$ & 696 & Orthic Brown & Sept. (3); Oct. (3) & Oct. (2); Nov. (4) & 0.32 \\
\hline $\mathrm{C}$ & 696 & Orthic Brown & Sept. (3); Oct. (3) & Oct. (2); Nov. (4) & 0.32 \\
\hline D & 170 & Orthic Brown & May (3); June (3) & Sept. (2); Oct. (4) & 0.67 \\
\hline $\mathrm{E}$ & 344 & Orthic Brown & May (2); June (4) & Oct. (2); Nov. (4) & 0.57 \\
\hline \multicolumn{6}{|c|}{ Solonetzic } \\
\hline A & 1765 & Bn Solod. Solon. ${ }^{3}$ & Aug. (1); Sept. (6) & Oct. (1); Nov. (5) & 0.25 \\
\hline A & 1765 & Bn Solod. Solon. & Aug. (1); Sept. (6) & Oct. (1); Nov. (5) & 0.25 \\
\hline B & 1330 & Bn Solod. Solon. & May (2); Aug. (4) & Oct. (2); Nov. (4) & 0.48 \\
\hline B & 1330 & Bn Solod. Solon. & May (2); Aug. (4) & Oct. (2); Nov. (4) & 0.48 \\
\hline
\end{tabular}

Month when grazing started or ended and the number of years (out of 6) when action was implemented.

${ }^{2}$ The recommended stocking rate for range in good condition is $0.61 \mathrm{AUM} \mathrm{ha}^{-1}$ (Wroe et al. 1988).

${ }^{3}$ Brown Solodized Solonetz.

\section{Sampling}

Soil and vegetation were sampled inside and outside each exclosure. Sampling inside the exclosure occurred in the center, either along a transect or at a central point, that were paired with equivalent samples taken $5 \mathrm{~m}$ outside the exclosure. The proximity of the outside transect to the exclosure ensured minimal spatial variation while avoiding a potential edge-effect produced by livestock distribution. We saw no evidence of increased animal activity, expressed by trails, fecal loading, or increased grazing pressure, immediately adjacent to the exclosures.

\section{Soil}

A soil survey was carried out in August 1993 by describing the landform and a single pedon in the center and outside of each exclosure. A physical description of soil in the Ah horizon included the depth, stoniness, color, texture, and alkalinity. Soils were sampled in July and September, 1997, for moisture and in September, 1997, for chemical analyses. The Ah (=A1) horizons were sampled in 3 subplots, spaced about $7 \mathrm{~m}$ apart, that were pooled giving 1 composite sample each for inside and outside the exclosure. The soils were screened ( $2-\mathrm{mm}$ sieve) to remove the macro-organic matter, dried, and ground to pass a $0.5-\mathrm{mm}$ sieve. Moisture content was determined gravimetrically. Bulk density of the Ah was estimated in September, 1998, by extract- 
ing undisturbed samples (15-mm dia.) to the depth of the Ah horizon. The cores were oven-dried, their mass obtained and their bulk densities calculated. Previous tests had shown that the $15-\mathrm{mm}$ core diameter provided a similar estimate of bulk density as the $3-\mathrm{cm}$ core providing the soil was stone-free (Unpublished data, Dormaar).

Soil $\mathrm{pH}$ was measured in $0.01 \mathrm{M} \mathrm{CaCl}_{2}$ (solution:soil ratio of $2: 1$ ). Total $\mathrm{C}$ and $\mathrm{N}$ were determined by dry combustion in a Carlo Erba NA 1500 Analyzer while total $\mathrm{P}$ was determined as per $\mathrm{Na}_{2} \mathrm{CO}_{3}$ fusion outlined by Jackson (1958). Available P $\left(\mathrm{N}_{\mathrm{a}} \mathrm{HCO}_{3}\right.$-soluble phosphorus) was determined as described by Olsen et al. (1954). Particle size distribution was determined by the hydrometer method as per Sheldrick and Wang (1993). Total C and $\mathrm{N}$ were calculated in tonne $\mathrm{ha}^{-1}$ for the depth of the surface horizon using the formula: concentration $\mathrm{x}$ bulk density $\mathrm{x}$ soil volume.

\section{Vegetation}

Herbage biomass and species cover were sampled along a single permanent, 10-m transect established both inside and outside each exclosure. Twenty, 20 x 50$\mathrm{cm}$ quadrats were placed along the transect at $0.5-\mathrm{m}$ intervals (beginning $0.5 \mathrm{~m}$ from one end) but alternately staggered on either side to increase the effective separation. Ten alternate quadrats were sampled in 1996 and the remainder in 1997. Species cover was sampled according to Daubenmire (1959) but due to time constraints, only 7 exclosures were sampled in 1996 and the remaining 8 in 1997. Estimates of foliar cover were made in alternate quadrats at each site and were aided with the use of a $100 \mathrm{~cm}^{2}$ template that provided a standard. Standing biomass and fallen litter were harvested at ground level in all quadrats after plant cover was estimated as well as in those exclosures where cover estimates were not made. This ensured that biomass estimates were made in all exclosures in both years. Moss, lichen, and bare ground cover were estimated after the standing biomass and fallen litter had been removed. Therefore, percent bare ground represented: $100 \%$ (\% area of moss $+\%$ area of lichen $+\%$ basal area of live vegetation).

Standing biomass was partitioned into annual net primary production and standing litter by pooling the standing biomass of 10 quadrats in each experimental unit, mixing the herbage and subsampling at least $10 \%$ of the total mass. The subsampled herbage was hand-sorted into current annual production and previous years' production. The proportion of these components was applied to the pooled total to estimate annual net primary production and standing litter. Each component was dried, weighed, and ground to pass a 100mesh screen $(149 \mu \mathrm{m})$ in preparation for chemical analyses. A representative subsample of herbage was analyzed for total $\mathrm{C}$ and $\mathrm{N}$ concentrations by an automated dry combustion technique (Carlo Erba ${ }^{\mathrm{TM}}$, Milan, Italy).

Vegetation was sampled from 4 July to 27 July in 1996 and from 16 June to 20 July in 1997. In 1996, grazing had begun in paddocks containing 2 exclosures by the time of sampling. In those cases, the quadrats were examined and discarded if evidence of grazing in the current year was found. This resulted in 1 quadrat being deleted from the data.

\section{Categorizing exclosures}

Each exclosure was categorized into 1 of 2 types based primarily on soil and verified by an independent examination of species composition using De-trended Correspondence Analysis (Gauch 1982) to establish similarity or dissimilarity in plant communities by transect. The ordination scores were plotted in 3 dimensional "species space" and differences in community types were inferred from their eigenvalues. As a result, 11 exclosures were placed in the Chernozemic soil type and 4 in the Solonetzic soil type (Table 1).

\section{Statistical analyses}

Diversity statistics were calculated for each transect including species numbers, evenness and the Shannon index for both native species only and all species. The Shannon index $\left(\mathrm{H}^{\prime}\right)$ is defined as $-\Sigma[\mathrm{Pi} \mathrm{x}$ $\ln (\mathrm{Pi})]$ where $\mathrm{Pi}$ is the importance probability in element i. Richness is an estimate of the number of species present while evenness $=\mathrm{H}^{\prime} / \ln$ (Richness) (Pielou 1977). Soil and biomass indices were analyzed using mixed effects ANOVA (SAS Institute Inc. 1999) for an unbalanced design with block ( $n=11$ or 4$)$ as the random variable nested in soil type $(n=2)$ as a fixed effect with grazing treatment $(\mathrm{n}=$ 2 ). Year was also included as a fixed effect in an analysis of biomass components. Where necessary, paired means were compared with single degree of free- dom contrasts. Foliar cover of selected species, and species indices, were analyzed as a randomized complete block design for each soil type across sampling years. Pooling across years was justified because the grazing effect was blocked by each exclosure and the treatment effect could be considered stabilized after 70 years. Plant cover was first normalized by the arcsine square root transformation (Steel and Torrie 1980) before analysis.

Species richness, evenness, and diversity were related to site physical and chemical characteristics (total phosphorus, available phosphorus, percent clay, percent sand, depth of Ah horizon, soil bulk density, soil carbon concentration, soil nitrogen concentration, bare ground, surface litter mass, and percent cover of Selaginella densa Rydb) with stepwise regression analyses (SAS Institute Inc. 1999) where the probability of any variable needed for inclusion was less than 0.15 . The analyses were made separately for both grazed and protected areas but across soil type.

\section{Results}

The effect of protection from grazing on annual net primary production, standing litter, and standing crop was dependent on soil type (Table 2). Protection resulted in greater herbage yields $(\mathrm{P}<0.05)$ on the Chernozemic soil type but had no effect ( $\mathrm{P}$ $>0.10$ ) on the Solonetzic soil type. Standing crop across all soil types averaged 160 and $130 \mathrm{~g} \mathrm{~m}^{-2}$ in 1996 and 1997 , respectively (Data not shown). The effect of protection on standing crop was different between years $(P=0.023)$. In 1996 and 1997 the protected treatment yielded 175 and $141 \%$ of the grazed treatment, respectively (Data not shown).

The response of annual net primary production and standing litter to grazing were affected by soil type ( $P=0.056$ and 0.045 , respectively). Although the trends in relation to grazing were the same on each type, the magnitude of response was less on the Solonetzic soil type than on the Chernozemic soil type (Table 2).

Nitrogen concentration in plant tissue of annual net primary production and standing litter was not affected by protection ( $\mathrm{P}$ $>0.10)$ but it was greater $(\mathrm{P}<0.001)$ in 1997 than in 1996. The standing crop was sampled 1 to 2 weeks earlier in 1997 than in 1996 that might have resulted in less senescent herbage having a greater nitro- 
Table 2. Herbage biomass after 70 years of protection from livestock grazing in Mixed Prairie plant communities on Chernozemic and Solonetzic soils.

\begin{tabular}{|c|c|c|c|c|}
\hline Factors & $\mathrm{ANPP}^{1}$ & Standing litter & Fallen litter & Standing crop $^{2}$ \\
\hline & $-\cdots$ & 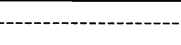 & 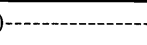 & ---------- \\
\hline \multicolumn{5}{|l|}{ Chernozemic $(n=11)$} \\
\hline Grazed & $92 \mathrm{a}$ & $28 \mathrm{a}$ & $67 \mathrm{a}$ & $120 \mathrm{a}$ \\
\hline Ungrazed & $129 \mathrm{~b}$ & $94 \mathrm{~b}$ & $184 \mathrm{~b}$ & $223 \mathrm{~b}$ \\
\hline \multicolumn{5}{|l|}{ Solonetzic $(n=4)$} \\
\hline Grazed & $78 \mathrm{a}$ & $26 \mathrm{a}$ & $72 \mathrm{a}$ & $104 \mathrm{a}$ \\
\hline Ungrazed & $79 \mathrm{a}$ & $53 \mathrm{a}$ & $133 \mathrm{a}$ & $132 \mathrm{a}$ \\
\hline Soil & 0.033 & 0.028 & 0.471 & 0.028 \\
\hline Graze & 0.047 & $<0.001$ & 0.005 & 0.002 \\
\hline Soil x Graze & 0.056 & 0.045 & 0.301 & 0.044 \\
\hline Year & 0.399 & 0.001 & 0.877 & 0.002 \\
\hline Soil x Year & 0.579 & 0.918 & 0.161 & 0.666 \\
\hline Graze x Year & 0.064 & 0.120 & 0.534 & 0.023 \\
\hline Soil x Graze x Year & 0.533 & 0.919 & 0.915 & 0.744 \\
\hline
\end{tabular}

${ }_{1}^{1}$ Annual net primary production.

${ }^{2} \mathrm{ANPP}+$ standing litter.

${ }^{a, b}$ Means with the same letter within subset of columns are not significantly different $(\mathrm{P}>0.05)$ as tested by single degree of freedom contrasts.

gen concentration. The net effect of nitrogen concentration and standing crop biomass resulted in greater $(\mathrm{P}=0.002)$ nitrogen mass on protected than on grazed sites (Table 3) although the effect was modified by year $(P=0.048)$. Nitrogen mass was marginally different between soil types ( $\mathrm{P}$ $=0.073)$. In annual net primary production and standing litter, the concentration of carbon was greater on the Chernozemic soil type than on the Solonetzic soil type ( $\mathrm{P}=0.056$ and 0.002 , respectively). The $\mathrm{C}: \mathrm{N}$ ratio of standing litter was influenced by an interaction between grazing and soil type $(\mathrm{P}=0.041)$.

On the Chernozemic soil type, protection from grazing resulted in an increase in the cover of $P$. smithii $(\mathrm{P}=0.049)$ and Tragopogon dubius Scop., and in a decrease of Bouteloua gracilis (H.B.K.) Lag ex Steud. ( $\mathrm{P}=0.004)$ and Poa sandbergii Vasey $(\mathrm{P}=0.009$, Table 4$)$. Species cover differences were not detected $(\mathrm{P}>$ $0.10)$ on the Solonetzic soil type. We could not detect any grazing effect $(\mathrm{P}>$ 0.10 ) on species richness and evenness on either soil type and only diversity among native species on the Chernozemic soil

Table 3. Carbon and nitrogen concentrations of herbage biomass, their $\mathrm{C}: \mathrm{N}$ ratios, and mass of nitrogen after 70 years of protection from livestock grazing in Mixed Prairie plant communities on Chernozemic and Solonetzic soils.

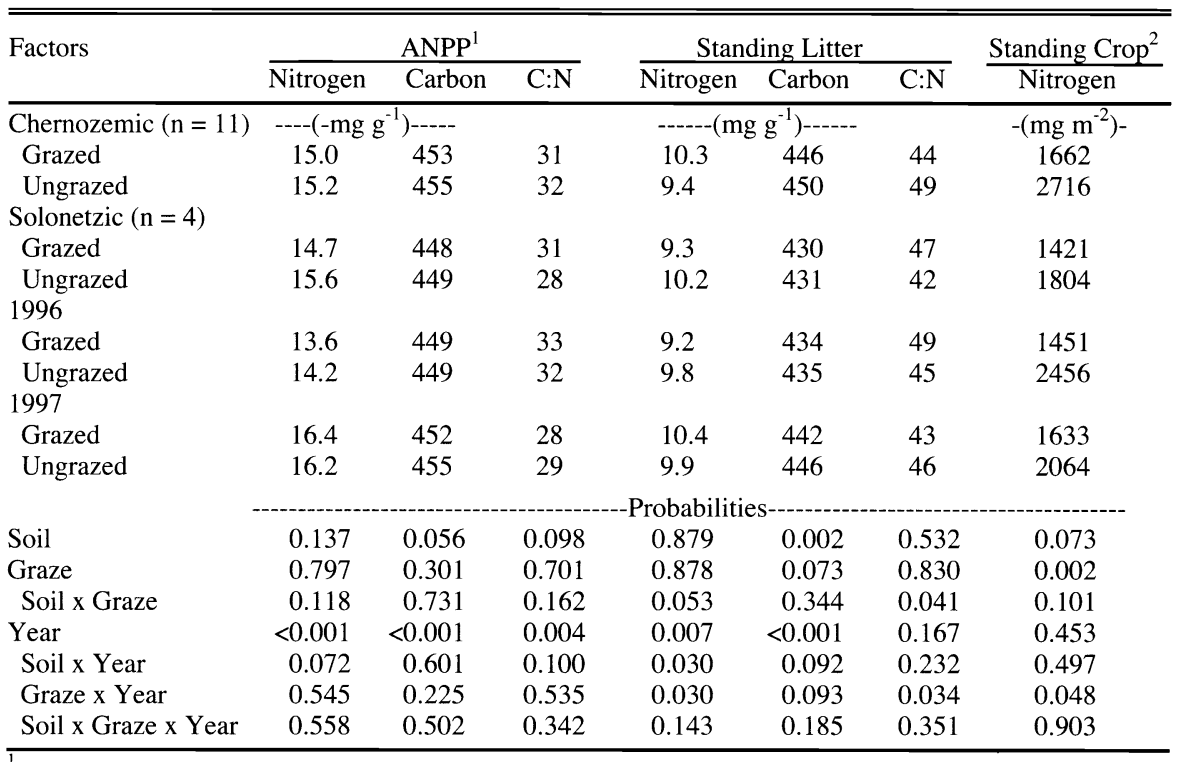

${ }_{2}^{1}$ Annual net primary production.

${ }^{2}$ Annual net primary production plus standing litter. type tended $(\mathrm{P}=0.096)$ to decline with protection.

Species richness, evenness, or diversity were not related $(P>0.10)$ to any tested physical or chemical soil variable on the protected areas. On grazed areas, species richness was related to the mass of ground litter $\left(b=0.077, r^{2}=0.27, P=0.049\right)$, concentration of available phosphorus $(\mathrm{b}=$ 1.03, $\mathrm{r}^{2}=0.20, \mathrm{P}=0.053$ ), and percent cover of Selaginella densa $\left(\mathrm{b}=0.046, \mathrm{r}^{2}=\right.$ $0.11, \mathrm{P}=0.116)$. For the model, $\mathrm{R}^{2}=0.58$ $(\mathrm{P}=0.018)$. Species diversity was related to soil bulk density $\left(b=-0.47, r^{2}=0.46, P\right.$ $=0.005)$ and the concentration of total available phosphorus $\left(b=-2.02, r^{2}=0.12\right.$, $\mathrm{P}=0.096)$. For the model, $\mathrm{R}^{2}=0.58(\mathrm{P}=$ 0.006). Species evenness was related only to soil bulk density $\left(b=-0.16, r^{2}=0.45, P\right.$ $=0.006$ ).

Of the soil properties measured in the Ah horizon, only soil moisture was affected $(\mathrm{P}<0.050)$ by protection while only depth of Ah and bulk density were affected $(P=0.020$ and $<0.001$, respectively) by soil type (Table 5 ). The effects of protection were similar $(\mathrm{P}>0.10)$ for all measured properties on each soil type.

\section{Discussion}

Protection from grazing after 70 years did not produce substantive effects among measured variables that would indicate deterioration of the plant or soil in 2 Mixed Prairie communities. Evidence that might be interpreted to indicate deterioration was a marginally depressed species diversity compared with grazed areas. Nevertheless, species richness was not affected by protection, suggesting that grazing did not affect the presence of a species but rather the abundance of the species; an observation that is reflected by shifts in plant cover particularly of $P$. smithii, B. gracilis, and $P$. sandbergii (Table 4).

Community changes appear to have occurred on the Chernozemic sites, since the exclosures were constructed in 1927, with a marked reduction in the composition of B. gracilis from about $55 \%$ in 1929 as determined by basal area (Clarke et al. 1947) to about 8 and $21 \%$ as determined by cover on protected and grazed treatments, respectively (calculated from Table 4). The high proportion of B. gracilis in 1929 may indicate previous heavy grazing pressure, drought, or both as these condi- 
Table 4. Properties of a Mixed Prairie plant community after $\mathbf{7 0}$ years of protection from livestock grazing on Chernozemic and Solonetzic soils.

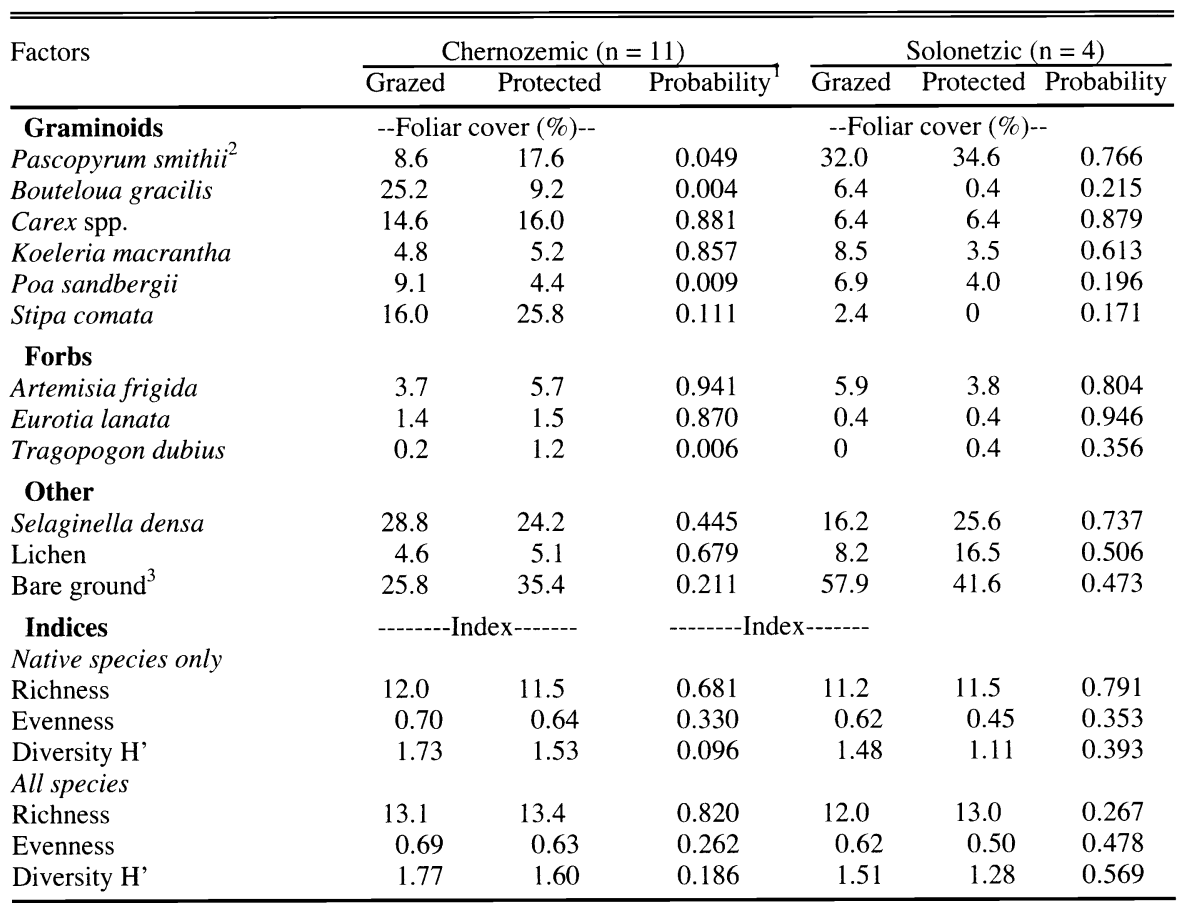

${ }_{1}^{1}$ Probabilities for percent plant cover were determined on data transformed by the arcsine square root before analyses.

${ }_{3}^{2}$ Nomenclature follows Moss (1983).

${ }^{3}$ Estimated as: $100 \%$ - (\% area of moss $+\%$ area of lichen $+\%$ basal area of live vegetation)

tions favor B. gracilis in the Mixed Prairie and disadvantage the larger $\mathrm{C}_{3}$ grasses. Weather records prior to 1929 from Medicine Hat $\left(49^{\circ} 03^{\prime}, 110^{\circ} 40^{\prime}\right)$ show a 28-year average annual precipitation of $295 \mathrm{~mm}$ (Unpublished data) but records of stocking rates were not available.

Grazing by large herbivores is the greatest disturbance imposed on these grasslands since fires were controlled. While the impact of protection from cattle grazing on soil enzymes and $\mathrm{N}$ constituents can be detected within 5 years (Dormaar et al. 1997), perhaps the most significant
Pickett 1991). Nevertheless, in our study litter did not impede species richness but appeared to enhance the establishment of T. dubius, a biennial that depends on seedling establishment for survival.

Annual net primary production is responsive to litter biomass (Willms et al. 1993) that conserves soil moisture (Table $5)$. While litter mass can inhibit production in mesic associations such as the Fescue (Willms unpublished data) or Tallgrass Prairies (Weaver and Rowland 1952, Penfound 1964), there is no evidence that litter accumulation can reach masses that impair production on the more arid region of the Mixed Prairie. Schuman et al. (1999) reported similar live aboveground biomass within exclosures and lightly grazed Mixed Prairie grassland that had 2,870 and 1,650 $\mathrm{kg} \mathrm{ha}^{-1}$ litter. Smoliak (1965) applied straw at rates of $11,000 \mathrm{~kg}$ $\mathrm{ha}^{-1}$ on a Stipa-Bouteloua community and found immediate suppression of herbage yield; but 1 year after application the treatment produced almost $200 \%$ more biomass than the control.

Nitrogen mass in the standing crop was directly related to biomass as its concentration was similar in each herbage type ( $P$ $>0.10$ ). Consequently the protected site had the greatest mass of $\mathrm{N}$ aboveground. This suggests that $\mathrm{N}$ mineralization was greater in protected sites, to supply the increased demand for growth, since total $\mathrm{N}$ was similar on both protected and grazed sites. This might be achieved by a more mesic soil environment enhanced by the greater mass of litter. However, this proposed mechanism disagrees with the observations of Shariff et al. (1994) who report greater soil $\mathrm{N}$ mineralization with moderate vs no grazing on a Mixed Prairie site in North Dakota.

Table 5. Soil properties of the Ah horizon after 70 years of protection from livestock grazing in Mixed Prairie plant communities on Chernozemic and Solonetzic soils.

\begin{tabular}{|c|c|c|c|c|c|c|c|c|c|c|c|}
\hline \multirow[t]{2}{*}{ Factors } & \multirow[t]{2}{*}{$\mathrm{P}_{\text {total }}$} & \multirow[t]{2}{*}{$\mathrm{P}_{\text {available }}$} & \multirow{2}{*}{\multicolumn{2}{|c|}{ Nitrogen }} & \multicolumn{2}{|c|}{ Carbon } & \multirow[t]{2}{*}{$\mathrm{pH}$} & \multicolumn{2}{|c|}{$\mathrm{Ah}$} & \multicolumn{2}{|c|}{ Soil moisture } \\
\hline & & & & & & & & Depth & $\mathrm{Bd}^{2}$ & July 9 & Sept. 11 \\
\hline Chernozemic $(\mathrm{n}=11)$ & $\left(\mathrm{g} \mathrm{kg}^{-1}\right)$ & $\left(\mathrm{mg} \mathrm{kg}^{-1}\right)$ & $\left(\mathrm{mg} \mathrm{g}^{-1}\right)$ & $\left(\mathrm{t} \mathrm{ha}^{-1}\right)^{1}$ & $\left(\mathrm{mg} \mathrm{g}^{-1}\right)$ & $\left(\mathrm{t} \mathrm{ha}^{-1}\right)$ & & $(\mathrm{cm})$ & $\left(\mathrm{g} \mathrm{cm}^{-3}\right)$ & \multicolumn{2}{|c|}{$--(\%)--$} \\
\hline Grazed & 0.36 & 6.17 & 1.62 & 1.39 & 16.6 & 14.0 & 6.03 & 6.6 & 1.32 & 5.0 & 2.5 \\
\hline Ungrazed & 0.37 & 6.21 & 1.78 & 1.52 & 17.3 & 14.7 & 6.05 & 7.1 & 1.19 & 9.2 & 3.5 \\
\hline \multicolumn{12}{|l|}{ Solonetzic $(n=4)$} \\
\hline Grazed & 0.32 & 5.75 & 1.44 & 0.94 & 13.4 & 8.7 & 6.52 & 3.2 & 2.29 & 7.0 & 4.1 \\
\hline Ungrazed & 0.33 & 5.98 & 1.38 & 1.66 & 13.2 & 15.7 & 6.41 & 4.0 & 2.33 & 9.5 & 5.2 \\
\hline \multicolumn{12}{|l|}{ Effects } \\
\hline Soil & 0.253 & 0.725 & 0.240 & 0.696 & 0.152 & 0.565 & 0.107 & 0.020 & $<0.001$ & 0.632 & 0.166 \\
\hline Graze & 0.363 & 0.889 & 0.399 & 0.184 & 0.618 & 0.194 & 0.200 & 0.375 & 0.790 & 0.050 & $<0.001$ \\
\hline Soil x Graze & 0.884 & 0.920 & 0.095 & 0.344 & 0.460 & 0.290 & 0.090 & 0.825 & 0.636 & 0.576 & 0.886 \\
\hline
\end{tabular}

The mass is expressed for the volume defined by the depth of the Ah horizon.

${ }^{2}$ Bulk density. 
Within a common environment the rates of litter decomposition between grazed and protected sites are expected to be comparable based on similar $(\mathrm{P}>0.10) \mathrm{C}: \mathrm{N}$ ratios (Table 3, Taylor et al.1989) and composition of the most productive forage species (Table 4). However, trampling by cattle may enhance decomposition by compacting the litter and increasing its contact with the soil, thus exposing it to a potentially more humid and microbial-rich environment. Presumably the discrepancy in litter mass between grazed and protected areas was determined by the effects of trampling and differences in primary production.

As a component of the cryptogamic crust, lichen cover was expected to be greatest with protection from livestock grazing (Anderson et al. 1982) as trampling can fragment the mass. The role of lichen in the arid grassland is generally viewed as positive in stabilizing the soil, fixing nitrogen by blue-green algae, and enhancing water infiltration. However, it may impair seedling establishment (McIlvanie 1942), a function that is likely unimportant in an established community. In the present study, lichen cover did not increase significantly $(\mathrm{P}>0.10)$ with protection (Table 4).

The effect of protection on species diversity appears to be dependent on the moisture conditions of the site with diversity decreasing on relatively mesic sites and increasing on more arid sites (Milchunas and Lauenroth 1993). According to this generalization, diversity in the present study should increase with protection, but this failed to materialize. Bai et al. (2001) also report lower diversity with protection on semiarid sites in the Northern Great Plains.

With a few exceptions, the effects of protection on plant variables produced similar trends on both Chernozemic or Solonetzic soil types although significant $(\mathrm{P}<0.10)$ effects tended to be found only on the Chernozemic soil type. The most significant difference between the soil types was a greater response to protection of annual net primary production on the Chernozemic than the Solonetzic soil type. The cause of this effect is not clear but one might speculate on the lower production potential of the Solonetzic soil type produced by greater physical and chemical limitations of the soil that impedes root growth and reduces water availability. Also, the Solonetzic soil type does not support $S$. comata, 1 of the more productive grass species on the Chernozemic soil type that also decreases with grazing pressure. Therefore, the opportunity for impacting annual net primary production is greater on the more productive Chernozemic soil type.

Marginal differences $(P=0.095)$ in the response of soil $\mathrm{N}$ to grazing between the Chernozemic and Solonetzic soil types may also reflect greater forage utilization of the former by cattle. Total soil $\mathrm{N}$ can decrease with grazing if the $\mathrm{N}$ removed is not completely replaced by atmospheric inputs. Frank et al. (1995) reported greater total soil $\mathrm{N}$ in an exclosure in a Mixed Prairie community that had been protected from grazing for almost 80 years than on grazed areas. On shortgrass steppe, Lauenroth and Milchunas (1991) estimate that atmospheric inputs are greater than all losses, resulting in a net annual $\mathrm{N}$ gain. Therefore, since the productivity of Solonetzic soil is less than the Chernozemic soil, and removal through utilization might follow a similar pattern, an interaction of soil type and grazing treatment might be expected.

\section{Conclusion}

We found little evidence that 70 years of protection from large animal disturbance had any detrimental effect on plant communities or soil quality of the Chernozemic or Solonetzic soil types. Conversely, most evidence suggested a neutral or beneficial effect as reflected in soil chemistry, cover of preferred native grasses, and annual net primary production. The effect of protection appeared largely driven by the accumulation of litter mass that benefits primarily the Chernozemic soil type. Lack of effect on the Solonetzic soil type does not indicate degradation but rather a non-response due to protection.

\section{Literature Cited}

Anderson, D.C., K.T. Harper, and R.C. Holmgren. 1982. Factors influencing development of cryptogamic soil crusts in Utah deserts. J. Range Manage. 35:180-185.

Bai, Y., Z. Abouguendia, and R.E. Redmann. 2001. Relationship between plant species diversity and grassland condition. J. Range Manage. 54:177-183.

Clarke, S.E., J.A. Campbell, and J.B. Campbell. 1942. An ecological and grazing capacity study of the native grass pastures in southern Alberta, Saskatchewan, and
Manitoba. Publ.738, Tech. Bull. 44, Dept. Agr., Ottawa, Ont.

Clarke, S.E., E.W. Tisdale, and N.A. Skoglund. 1947. The effects of climate and grazing practices on short-grass prairie vegetation in southern Alberta and southwestern Saskatchewan. Publ. 747, Tech. Bull. 46, Dept. Agr., Ottawa, Ont.

Coupland, R.T. 1950. Ecology of Mixed Prairie in Canada. Ecol. Mono. 20:272-315.

Daubenmire, R.F. 1959. A canopy-coverage method of vegetational analysis. Northwest Sci. 33:43-64.

Dormaar, J.F., B.W. Adams, and W.D. Willms. 1997. Impacts of rotational grazing on mixed prairie soils and vegetation. J. Range Manage. 50:647-651.

Facelli, J.M. and S.T.A. Pickett. 1991. Plant litter: Its dynamics and effects on plant community structure. Bot. Rev. 57:1-32.

Frank, A.B., D.L. Tanaka, L. Hofmann, and R.F. Follet. 1995. Soil carbon and nitrogen of Northern Great Plains grasslands as influenced by long-term grazing. J. Range Manage. 48:470-474.

Gauch, H. 1982. Multivariate Analysis in Community Ecology. Cambridge University Press. Cambridge, England.

Jackson, M.L. 1958. Soil chemical analysis. Prentice-Hall, Inc., Englewood Cliffs, N.J.

Lauenroth, W.K. and D.G. Milchunas. 1991. Short-grass steppe. p. 183-226. In: R.T. Coupland (ed), Natural Grasslands: Introduction and Western Hemisphere. Ecosystems of the World Vol 8A, Elsevier Press, New York, N.Y..

Lauenroth, W.K., D.G. Milchunas, J.L. Dodd, R.H. Hart, R.K. Heitschmidt, and L.R Rittenhouse. 1994. Effects of grazing on ecosystems of the Great Plains, p. 69-100. In: Martin Vavra, William A. Laycock, and Rex D. Pieper (eds.), Ecological implications of livestock herbivory in the West. Soc. for Range Manage., Denver, Colo.

McIlvanie, S.K. 1942. Grass seedling establishment and productivity-overgrazed vs protected range soils. Ecol. 23:228-231.

Milchunas, D.G. and W.K. Lauenroth. 1993. Quantitative effects of grazing on vegetation and soils over a global range of environments. Ecol. Mono. 63:327-366.

Moss, E.H. 1983. Flora of Alberta. 2nd Ed., Univ. Toronto Press, Toronto, Ont.

Olsen, S.R., C.V. Cole, F.S. Watanabe, and L.A. Dean. 1954. Estimation of available phosphorus in soils by extraction with sodium bicarbonate. USDA, Circ. 939, U.S. Government Printing Office, Washington, D.C.

Pielou, E.C. 1977. Mathematical Ecology. John Wiley \& Sons, Toronto, Ont.

Penfound, W.T. 1964. Effects of denudation on the productivity of grassland. Ecol. 45:838-845.

Savory, A. 1983. The Savory Grazing Method or Holistic Resource Management. Rangelands 5:155-159.

SAS Institute Inc. 1999. SAS/STAT Users Guide. Version 8, SAS Institute Inc., Cary, N.C., 
Shariff, A.R., M.E. Biondini, and C.E. Grygiel. 1994. Grazing intensity effects on litter decomposition and soil nitrogen mineralization. J. Range Manage. 47:444-449.

Sheldrick, B.H. and C. Wang. 1993. Particle size distribution, p. 499-511. In: M.R. Carter (ed), Soil Sampling and methods of analysis. Lewis Publishers, Boca Raton, Fla.

Schuman, G.E., J.D. Reeder, J.T. Manley, R.H. Hart, and W.A. Manley. 1999. Impact of grazing management on the carbon and nitrogen balance of a mixed-grass rangeland. Ecol. Appl. 9: 65-71.

Smoliak, S. 1965. Effects of manure, straw and inorganic fertilizers on Northern Great Plains ranges. J. Range Manage. 18:11-14.
Smoliak, S. 1986. Influence of climate conditions on production of Stipa-Bouteloua prairie over a 50 -year period. J. Range Manage. 39:100-103.

Smoliak, S. and H.F. Peters. 1952. Range and livestock management in the shortgrass prairie region of southern Alberta and Saskatchewan. Publ. 876. Dept. Agr., Ottawa, Ont.

Steel, R.G.D. and J.H. Torrie. 1980. Principles and Procedures of Statisitics: A Biometrical Approach. $2^{\text {nd }}$ ed., McGraw-Hill Book Co. N.Y.

Taylor, B.R., D. Parkinson, and W.F.J. Parsons. 1989. Nitrogen and lignin content as predictors of litter decay rates: A microcosm test. Ecol. 70:97-104.
Weaver, J.E. and N.W. Rowland. 1952. Effects of natural mulch on development, yield, and structure of native grassland. Bot. Gazette 114:1-19.

Willms W.D., S.M. McGinn, and J.F. Dormaar. 1993. Influence of litter on herbage production in the Mixed Prairie. J. Range Manage. 46:320-324.

Wroe, R.A., S. Smoliak, B.W. Adams, W.D. Willms, and M.L. Anderson. 1988. Guide to stocking rates for Alberta grasslands 1988. Alberta Forest. Lands and Wildl., Public Lands, Edmonton, Alberta.

\section{JRM CD-ROM Available}

The complete 2001 year of the Journal of Range Management papers, Volume 54, is available on a CD-ROM. Each of the papers published in 2001 are presented in their

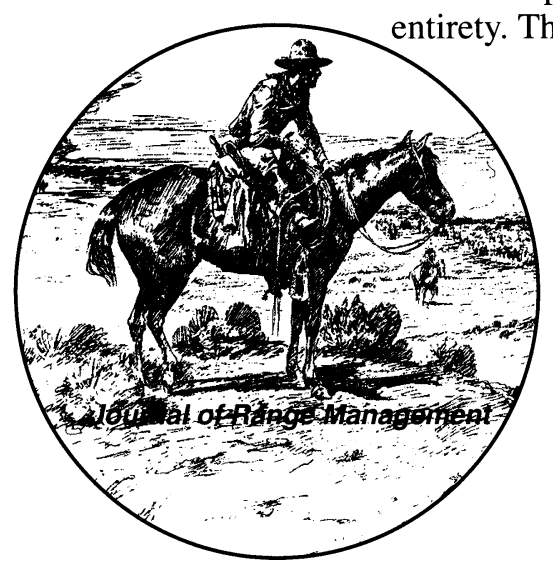

Gary Frasier

7820 Stag Hollow

Loveland, Colorado 80538

E-mail gfrasier@aol.com

Adobe Acrobat is necessary to access the files 